\title{
Ice Pack
}

National Cancer Institute

\section{Source}

National Cancer Institute. Ice Pack. NCI Thesaurus. Code C151989.

A container filled with frozen material that retains its temperature for an extended period. 